\title{
Peran Pemerintah Daerah dalam Penanganan Anak Putus Sekolah di Kecamatan Wawonii Utara Kabupaten Konawe Kepulauan
}

\author{
Elsa Triana ${ }^{1}$; Rahman ${ }^{2}$; Saidin ${ }^{3}$ \\ ${ }^{123}$ Universitas Halu Oleo, elsatriana45@gmail.com
}

\begin{abstract}
Abstrak
Penelitian ini bertujuan untuk mengetahui dan menganalisis peran pemerintah daerah dalam menekan anak putus sekolah dikabupaten Konawe Kepulauan Kecamatan Wawonii Utara dan mengambarkan faktor-faktor penyebab anak putus sekolah di Kecamatan Wawonii Utara. Penelitian ini menggunakan pendekatan kualitatif, tipe penelitian adalah deskriptif. Adapun informan penelitian ini adalah kepala dinas, kepala sekolah SD,SMP,dan SMA, serta masyarakat. Data diperoleh dari hasil wawancara mendalam terhadap informan, observasi, dan dokumentasi selama kurang lebih satu bulan di lapangan. Data dianalisis seara deskriptif kualitatif. Hasil penelitian ini menjukan bahwa upaya atau peran pemerintah daerah dalam menekan anak putus sekolah di Kecamatan Wawonii Utara mengeluarkan kebijakan pemerintah berupa kebijakan di bidang pendidikan, bantuan dana pendidikan, pemberian beasiswa pendidikan bagi masyarakat miskin dan sosialisasi kepada masyarakat. Berdasakan kasus yang ditemukan penulis dilapangan faktor yang menjadi penyebab anak putus sekolah adalah lemahnya ekonomi, keluarga yang tidak harmonis, pernikahan diusia dini, pandangan masyarakat tentang pendidikan dan teman sebaya.
\end{abstract}

Kata kunci : Anak, Peran, Pemerintah, Penanganan, Sekolah.

\begin{abstract}
This study aims to determine and anayze the role of local goverment in suppressing school dropouts in the Konawe district of the North Wawonii subdistrict and to describe the factors that cause shool dropouts. This study uses a qualitative approach, the type of research is descriptive, while the omni research informent, principals of elementary, junior and senior high school, and the community. Data obtained from the result of indepth interviews with iformants, observations and dokumentation or approximately one month in the field. Data were analyzed descriptively qualitatively. The results of the study show that the efforts or local governments in emphasizing school dropouts in North Wawonii district issued a government policy on educational scholarships for the poor and socialization to the community. Based on the case found by the author in case found by the author in the field the factor that cause school dropouts are a family economy that is not harmonious, early age marriage, community views on education and peers.
\end{abstract}

Keywords : Child, Government, Handle, Role, School

\section{Pendahuluan}

Otonomi daerah sebagai salah satu bentuk desentralisasi pemerintahan, pada hakikatnya ditujukan untuk memenuhi kepentingan bangsa secara keseluruhan, yaitu upaya untuk lebih mendekati tujuan-tujuan penyelenggaraan pemerintahan untuk mewujudkan cita-cita masyarakat yang lebih baik, suatu 
masyarakat yang lebih adil dan lebih sejahtera.Desentralisasi diartikan sebagai penyerahan Urusan Pemerintahan oleh Pemerintah Pusat kepada daerah otonom berdasarkan Asas Otonomi (Pasal 1 ayat (8) UU nomor 23 Tahun 2014).

Berdasarkan asas desentralisasi tentunya pemerintah daerah mempunyai kewenangan dalam mengurus daerahnya sendiri, sehingga pemerintah daerah kini lebih leluasa dalam mengelolah serta meningkatkan potensi yang di miliki daerahnya termasuk sumber daya manusia. Sehingga pemerintah daerah mempunyai peranan penting dalam menjamin hak masyarakatnya, dikarenakan pemerintah daerah yang lebih dekat secara wilayah serta memahami dan mengetahui kondisi dan kebutuhan masyarakatnya, dalam hal ini kebutuhan dasar masyarakat yakni di bidang pendidikan. Hal ini tentunya sesuai dengan peranan pemerintah sebagai edukasional yang memberikan pengetahuan kepada masyarakat dalam membangkitkan kemampuan dan kesadarannya dalam memecahkan berbagai masalah yang dihadapinya dengan ilmu dan pengetahuan yang mereka miliki.

Pendidikan sebagai salah satu kunci penting dalam proses perkembangan untuk memajukan suatu bangsa dapat dikatakan demikian manakala tingkat pendidikan suatu negara dikatakan tinggi, setidaknya peradaban dan pola pikir masyarakat di Negara tersebut haruslah tinggi pula. Keberhasilan suatu Negara banyak tergantung pada kemajuan tingkat pendidikanya, di Indonesia sendiri banyak dijumpai berbagai masalah yang berkaitan dengan pendidikan, misalnya saja adalah putus sekolah.

Hal ini juga sejalan dengan amanat yang dituangkan dalam Pembukaan Undang-Undang Dasar 1945 pada salah satu butir yang tercantum disana dijelaskan bahwa adanya pencerdasan kehidupan bangsa, jelas ini merupakan tugas dan tanggung jawab yang besar. Bagaimana respon pemerintah dan masyarakat dalam menyikapi hal tesebut, karena secara tidak langsung orang yang tidak menyenyam pendidikan ataupun sudah dapat mengenyam akan tetapi putus di tengah jalan. Bisa saja berasal dari anak-anak yang cerdas, bahkan sebaliknya. Akan tetapi terlepas dari hal itu, harus dicarikan solusi yang tepat untuk mengatasinya. Pendidikan bagi kehidupan manusia merupakan kebutuhan utama yang tak dapat dikesampingkan, 
sebab pendidikan akan membentuk sikap mental manusia kepada perilaku budi pekerti luhur yang dapat membentuk keperibadian utama. Hal ini jelas telah di amanatkan oleh UUD 1945 Pasal 31 ayat (1) bahwa Setiap warga negara berhak mendapat pendidikan.

UU Nomor 20 Tahun 2003 tentang Sistem Pendidikan Nasional sebenarnya sudah mengamanatkan tentang pentingnya alokasi anggaran dana untuk pembiayaan dan pembangunan pendidikan ini. Dalam pasal 49 ayat (1) dikemukakan bahwa "Dana pendidikan selain gaji pendidik dan biaya pendidikan kedinasan dilalokasikan minimal 20\% dari Anggaran Pendapatan dan Belanja Negara (APBN) pada sektor pendidikan dan minimal 20\% dari Anggaran Pendapatan dan Belanja Daerah (APBD). Namun, amanat yang jelas-jelas memiliki dasar dan payung hukum tersebut dengan berbagai dalih dan alasan belum terlaksana secara maksimal, sehingga masih banyak masyarakat yang tidak bisa mengeyam pendidikan di bangku sekolah. Data Dinas Pendidikan menunjukkan masih ada kondisi anak putus sekolah yang terjadi di kabupaten Konawe Kepulauan setiap tahunnya menjadi ironi bagi pemerintah daerah, berdasarkan akomulasi data pada tahun 2017 jumlah anak putus sekolah di Kabupaten Konawe Kepulauan mencapai angka 103 setelah di identifikasi penyebabnya itu menikah di usia dini, ini adalah bukti kelemahan dalam pembinaan terhadap anak serta indikator atau faktor lainya adalah faktor ekonomi. Kondisi demikian dapat dimaknai bahwa masih adanya anak usia sekolah yang belum bersekolah. Kondisi anak putus sekolah untuk anak usia sekolah tentunya sangat memperhatinkan. Kondisi anak putus sekolah sendiri dapat disebabkan oleh berbagai faktor salah satunya disebabkan oleh faktor ekonomi.

Pemerintah Kabupaten Konawe Kepulauan bertanggung jawab dalam menjamin dan memenuhi hak dasar masyrakat akan layanan dan peningkatan pendidikan untuk menjamin hak setiap masyarakat untuk mengeyam pendidikan, demi menciptakan masyarakat yang berkualitas maju, mandiri, dan sejahtera dengan membangun keunggulan komparatif di masing-masing wilayah dan didukung oleh kapasitas SDM yang berkualitas, sesuai dengan visi dan misi pembangunan di Kabupaten Konawe Kepulauan. Olehnya itu, bertolak dari latar 
belakang diatas penulis kemudian tertarik untuk melakukan penelitian tentang "Peran Pemerintah Daerah Dalam Penanganan Anak Putus Sekolah Di Kecamatan Wawonii Utara Kabupaten Konawe Kepulauan”. Tujuan penelitian ini adalah sebagai berikut: Untuk mengetahui faktor-faktor yang menyebabkan anak putus sekolah di Kecamatan Wawonii Utara Kabupaten Konawe Kepulauan. Untuk mengetahui peran Pemerintah Daerah dalam menangani anak putus sekolah di Kecamatan Wawonii Utara Kabupaten Konawe Kepulauan.

\section{Metode}

Pendekatan yang digunakan dalam penelitian ini adalah pendekatan studi kasus, artinya penulis akan meneliti satu unit sosial yang berkaitan dengan fokus permasalahan secara lebih mendalam. Penulis menggunakan metode kualitatif karena permasalahan yang ada dinamis, kompleks dan penuh makna. Dan menggunakan tipe deskriptif yaitu dengan memberikan gambaran secara spesifik mengenai peran pemerintah daerah dalam pengentasan anak putus sekolah di Kecamatan Wawonii Utara Kabupaten Konawe Kepulauan. Penelitian ini dilakukan di Kabupaten Konawe Kepulauan, di Dinas Pendidikan, Pemuda dan Olahraga Kabupaten Konawe. Dengan pertimbangan bahwa komponen-komponen tersebut berperan penting dalam proses pemberdayaan masyarakat dan pengentasan anak putus sekolah. Penelitian ini akan dilaksanakan selama 1 bulan yaitu bulan April 2019 sampai selesai.

\section{Hasil dan Pembahasan}

\section{Faktor-Faktor Penyebab Anak Putus Sekolah}

\section{a. Faktor Keluarga}

Orang tua merupakan orang yang memiliki peranan sangat penting dalam menunjang hak anak terhadap pendidikannya. Namun, hubungan keluarga tidak harmonis dapat berupa kurangnya perhatian antar anggota keluaraga dan terkadang berupa perselisihan keluarga yang berdampak pada perceraian orang tua, dimana hubungan antar keluarga tidak saling peduli, keadaan ini merupakan dasar anak mengalami permasalahan yang serius dan hambatan dalam pendidikannya sehingga 
mengakibatkan anak mengalami putus sekolah. Dari wawancara yang dilakukan bahwa dua anak putus sekolah karna soal biaya dan perceraian orang tua mereka sehingga mereka tidak bisa melanjutkan sekolah mereka kejenjang yang lebih tinggi.

\section{b. Faktor Ekonomi}

Kondisi sosial ekonomi keluarga adalah keadaan atau kedudukan yang diatur sosial dan menetapkan sebuah keluarga dalam posisi tertentu dalam struktur masyarakat yang berkaitana dengan tingkat pendidikan dan pemenuhan kebutuhan keluarga sehingga mempengaruhi kebutuhan anak-anak dan pendidikannya. Hal ini karena tingkat pendidikan orang tua yang sangat minim dan pendapatan/penghasilan pokok maupun penghasilan sampingan yang didapatkan tidak mencukup untuk biaya hidup anak-anak mereka.

Dari hasil wawancara yang penulis lakukan ternyata yang menyebabkan anak mereka putus sekolah karena hal biaya ekonomi mereka yang tidak mencukupi atau pendapatan yang dihasilkan tidak memenuhi kebutuhan anak-anak mereka sehingga anak-anak mereka tidak bisa melanjutkan sekolah meski ada bantu dari pemerintah daerah.

\section{c. Faktor Keluarga}

Lingkungan tempat tinggal anak adalah salah satu faktor yang mempengaruhi terjadinya kegiatan dan proses belajar/pendidikan. Oleh sebab itu seyogyanya lingkungan tempat tinggal anak atau lingkungan masyarakat ini dapat berperan dan ikut serta di dalam membina kepribadian anak-anak kearah yang lebih positif. Suasana lingkungan sebenarnya sangat mempengaruhi proses belajar mengajar bagi anak. Lingkungan yang tentram, nyaman, damai akan mempunyai pengaruh yang baik kepada anak.

Dari hasi wawancara yang dilakukan bahwa ternyata teman sepergaulan sangat mempengaruhi terhadap kehidupan pada masa remaja. Karena remaja dalam masyarakat moderen seperti ini menghabiskan waktunya bersama teman sebayanya mereka. Pada masa remaja hubungan dengan teman sebaya meningkat secara dratis, dan pada saat yang bersamaan kedekatan hubungan remaja dengan orang tua menurun. 


\section{d. Pernikahan Dini}

Pernikahan dini yang terkadang berakibat pada terhentinya salah satu hak anak yaitu mendapatkan pendidikan. Pendidikan adalah salah satu cara untuk peningkatan kualitas hidup warga sementara pada sebagian besar kasus anak dengan pernikahan dini terhenti pendidikannya. Namun membiarkan anak putus sekolah adalah bentuk pelanggaran hak anak untuk mendapatkan pendidikan seperti anak seumuran mereka.

\section{e. Pandangan Masyarakat Akan Pendidikan}

Pandangan masyarakat terhadap pendidikan juga sangat berpengaruh terhadap keberhasilan anak dalam menempuh pendidikan di bangku sekolah. Pandangan masyarakat yang maju tentu berbeda dengan masyarakat yang keterbelakangan, masyarakat yang maju tentu pendidikan mereka maju pula, demikian pula anak-anak mereka akan menjadi bertambah maju pula pendidikannya dibanding dengan orang tua mereka. Maju mundurnya suatu masyarakat, bangsa dan negara juga ditentukan dengan maju mundurnya pendidikan yang dilaksanakan.

Masyarakat yang terpencil atau masyarakat yang tradisional juga beranggapan bahwa sekolah itu pada dasarnya sedikit sekali yang sesuai dengan kehendak mereka, misalnya begitu tamat sekolah langsung mendapatkan pekerjaan, sekolah hendaknya tidak memerlukan biaya yang banyak, dan tidak memerlukan waktu yang terlalu lama. Mungkin jika pendidikan yang ada itu dapat sesuai dengan kehendak mereka maka masyarakatpun juga akan mendukungnya, namun semua itu hanya keinginan mereka tanpa harus berjuang dan berusaha secara maksimal.

Masyarakat dalam hal ini harus memiliki pandangan dan tanggung jawab akan pentingnya pendidikan bagi setiap individu bagi mereka dan lebih mendukung setiap program pemerintah dalam peningkatan mutu pendidikan yang ada di Kabupaten. Pendidikan bukan hanya menjadi tanggung jawab pemerintah semata, namun setiap elemen seperti masyrakat memiliki perannya masing-masing untuk memenuhi hak dasar setiap anak akan pendidikan sesuai dengan salah satu arah 
pembangunan Kabupaten Konawe Kepulauan dalam pelayanan hak dasar yang diprioritaskan adalah hak atas layanan dan peningkatan pendidikan.

\section{Peran Pemerintah Daerah dalam Penanganan Anak Putus Sekolah} di Kecamatan Wawonii Utara Kabupaten Konawe Kepulauan

\section{a. Kebijakan di Bidang Pendidikan}

Kebijakan pemerintah daerah Kabupaten Konawe Utara Khususnya Kecamatan Wawonii Utara di bidang pendidikan tentunya sesuai dengan visi dan misi Kabupaten Konawe Kepulauan yakni meningkatkan akses masyarakat, khususnya masyarakat kurang mampu terhadap layanan pendidikan yang berkualitas di semua jenjang pendidikan, utamanya SD, SLTP dan SLTA seiring dengan peningkatan mutu dan kesejahteraan guru. Salah satu kebijakan pemerintah daerah dalam mengatasi permasalahan anak putus sekolah yang terjadi adalah gerakan penuntasan wajib belajar 12 tahun dalam bentuk surat edaran Bupati Konawe Kepulauan, yang telah diberikan kepada setiap perangkat pemerintahan yang ada di kecamatan, kelurahan atau desa, untuk kemudian disosialisaikan dan memberikan pemahaman kepada setiap masyarakat sebagai wujud tanggung jawab pemerintah dalam menjamin hak setiap masyrakat akan pendidikan.

Berdasarkan pengamatan penulis, nampaknya permasalahan pendidikan telah menjadi salah satu program prioritas dalam pembangunan yang ada di Kabupaten Konawe Kepulauan. Hal ini berangkat dari visi misi pembangunan, yang menfokuskan pada peningkatan dan pelayanan pendidikan sebagai hak dan kebutuhan dasar masyarakat. Namun dengan berbagai upaya yang dilakukan pemerintah tak akan berarti tanpa adanya kesadaran oleh setiap masyrakat akan pentingnya pendidikan dan merupakan hak dan kebutuhan setiap orang untuk mengenyam pendidikan.

\section{b. Bantuan Dana Pendidikan}

Pemerintah Kabupaten Konawe Kepulauan telah berupaya dalam mewujudkan peningkatan mutu pendidikan di Kabupaten dan di salurkan disetiap kecamatan. Salah satu indikator paling penting guna peningkatan mutu pendidikan di Kecamatan Wawonii Utara yakni penganggaran untuk membantu proses 
peningkatan kualitas terutama disektor pendidikan, dan diharapkan dapat membantu untuk mengurangi beban masyarakat dalam menghadapi masalah biaya pendidikan, sehingga dapat mengatasi anak putus sekolah yang terjadi di Kabupaten Konawe Kepulauan khususnya di Kecamatan Wawonii Utara. Untuk mencapai hal tersebut dibutuhkan keterlibatan semua unsur dan elemen masyarakat yang ada. Pada tahun 2015 pemerintah mengalokasikan anggaran Dana BOS (Bantuan Operasional Pendidikan) yang cukup besar ke Kabupaten Konawe Kepulauan, Sulawesi Tenggara, yakni mencapai angka 36 Miliar lebih atau meningkat Rp.10 Miliar dibanding tahun lalu. Dari hasil wawancara yang dilakukan bahwa dana bos ini sangat membantu masyarakat disana dalam hal soal pembayaran uang pendidikan bagia anak-anak mereka utuk bersekolah.

\section{c. Pemberian Beasiswa Pendidikan Bagi Masyarakat Miskin}

Diantara faktor-faktor penyebab anak tidak putus sekolah, kiranya faktor ekonomi terkadang menjadi faktor yang paling sering ditemui. Permasalahan kemiskinan sebagai faktor utama penyebab anak tidak dan atau putus sekolah, maka optimalisasi pemberian beasiswa menjadi alaternatif kebijakannnya. Dalam Program BSM (Bantuan Siswa Miskin) ekonomi dan jarak maka dengan adanya program Bantuan Siswa Miskin menjadi alternatif lain selain optimalisasi beasiswa. Program BSM merupakan program nasional dari Kementrian Pendidikan dan Kebudayaan yang dilaksanakan disetiap daerah dengan maksud untuk mengamankan upaya jangka panjang guna memutus rantai kemiskinan dengan memastikan masyarakat miskin bisa mengakses pendidikan, sehingga mutu sumber daya manusia Indonesia pada umumnya dan Kabupaten Konawe Kepulauan pada khususnya terus meningkat dan mampu bersaing dalam era masyarakat global. Program ini bertujuan :

1. Untuk menghilangkan halangan siswa miskin berpartisipasi untuk bersekolah dengan membantu siswa miskin memperoleh akses pelayanan pendidikan yang layak;

2. Mencegah siswa putus sekolah karena ketiadaan biaya;

3. Membantu siswa memenuhi kebutuhan dalam kegiatan pembelajaran,; 
4. Mendukung program Wajib Belajar Pendidikan Dasar Sembilan Tahun (bahkan hingga tingkat Sekolah Menengah Atas); serta

5. Membantu kelancaran program sekolah.

\section{d. Sosialisasi Kepada Masyarakat}

Selain mengeluarkan kebijakan dan program di bidang pendidikan pemerintah daerah juga gencar dalam melakukan sosialisasi kepada masyarakat sebagai upaya pembinaan terhadap masyarakat. Hal ini dilakukan dengan cara memberikan penjelasan mengenai pentingnya serta manfaat dari proses pendidikan/bersekolah kepada masyarakat melalui proses sosialisasi. Kondisi anak yang tidak dan putus sekolah karena perhatian orang tua yang kurang dan faktor budaya dapat di atasi melalui pendekatan tertentu oleh pemerintah daerah. Kurangnya perhatian dapat disebabkan karena rendahnya kesadaran orang tua tentang arti penting pendidikan. Begitu juga dengan faktor budaya. Faktor budaya yang dimaksudkan adalah adanya pandangan yang kurang tepat pendidikan yaitu, pendidikan belum tentu menjamin kehidupan yang lebih layak.

\section{Kesimpulan}

Berdasarkan hasil penelitian maka dapat dilihat hasil kesimpulan sebagai berikut. Faktor penyebab anak putus sekolah di Kecamatan Wawonii Utara yaitu keadaan keluarga yang tidak harmonis, lemahnya ekonomi keluarga, pergaulan bebas, pernikan diusia dini, pandangan masyarakat akan pendidikan dan mempengaruhi pola pikir mereka yang kurang peduli dengan pendidikan. Paling dominan yang mempengaruhi anak putus sekolah adalah pernikahan di usia dini dan faktor keluarga. Sehingga tahun 2018 mencapai angka 96 anak yang putus sekolah, tingkat SD berjumlah 15 anak, SMP berjumlah 27 anak dan SMA berjumlah 36 anak. Peran pemerintah daerah dalam menekan angka anak putus sekolah yang terjadi di Kecamatan Wawonii Utara adalah Kebijakan Pemerintah Daerah dalam menekan angka anak putus sekolah yakni berupa gerakan penuntasan wajib belajar 12 tahun sebagai wujud pemenuhan hak dasar masyarakat sesuai visi dan misi pembangunan pemberian bantuan dana, pemberian beasiswa pendidikan 
bagi masyarakat miskin, program BSM (Bantuan Siswa Miskin); dan juga bantuan dana BOS.

\section{Referensi}

Cohen, Bruce J. (1992). Sosiologi Suatu Pengantar. Jakarta. Rineka Cipta.

Driyakara. (1980). Driyakara tentang pendidikan. Yogyakarta: Yayasan kanisius

Gadjong, Agussalim Andi. (2007). Pemerintahan Daerah. Bogor: Ghalia Indonesia.

Gie, Liang. (1995). Pertumbuhan Pemrintahan Daerah di Negara Republik Indonesia Jilid III. Yogyakarta: Liberty Offset

Hasbullah. (2010). Otonomi Pendidikan: Kebijakan Otonomi Daerah dan Implikasinya Terhadap Penyelenggaraan Pendidikan. Jakarta: Rajawali Pers

Ahmadi (1990) Strategi Belajar Mengajar Keterampilan Berbahasa Dan Apresiasi Sastra. Malang : Yayasan Asah Asuh (YA3.Malang)

Idrus, Muhammad. (2007). Metode Penulisan Ilmu-ilmu Sosial (Pendekatan Kualitatif dan Kuantitatif). Yogyakarta:UII Press

Imron, Ali. (2002). Kebijaksanaan Pendidikan di Indonesia: Proses, Produk dan Masa Depannya. Jakarta: Bumi Aksara

Musfiqon, (2007 ). Menangani yang Putus Sekolah, UMSIDA : Sidoarjo

Komaruddin. (2001).Ensiklopedia Manajemen Edisi IX. Bumi Aksara. Jakarta.

Yuwono Tegug (2002). Manajemen Otonomi Daerah, Semarang: Clogapps Diponogoro University

Muhibbin Syah, (2010) Psikologi Pendidikan dengan Pendekatan Baru. Bandung: PT Remaja Rosdakarya

Nasution,S. (2010). Sosiologi Pendidikan. Jakarta: Bumi Aksara.

Notoatmodjo, Soekidjo. (2003). Pendidikan dan Perilaku Kesehatan I. Jakarta :Rineka Cipta.

Pamudji.(1985). Kerja Sama Antar Daerah dalam Rangka Membina Wilayah. Jakarta: Bina Aksara 
Peraturan Bupati Pinrang Nomor 11 Tahun 2008 Tentang Pelaksanaan Peraturan Daerah Kabupaten Pinrang Nomor 19 Tahun 2008 Tentang Organisasi Dan Tata Kerja Dinas Daerah Pemerintah Kabupaten Pinrang.

Peraturan Daerah Provinsi Sulawesi Selatan Nomor 4 Tahun 2009 Tentang Penyelenggaraan Pendidikan Gratis Di Provinsi Sulawesi Selatan.

Sedarmayanti. (2004). Good Governance (Kepemerintahan Yang Baik) Bagian Kedua Membangun Sistem Manajemen Kinerja Guna Meningkatkan Produktivitas Menuju Good Governance (Kepemerintahan Yang Baik), Bandung: Mandar Maju

Sindhunata. (2000). Menggagas Paradigama Baru Pendidikan "demokratisasi, Otonomi, Civil Society, Globalisasi. Yogyakarta: Kansius

Sugiyono. (2011). Metode Penulisan Kuantitatif, Kualitatif, Dan $R \&$ D. Bandung: Alfabeta

Tilaar, A, R. (2000). Paradigma Baru Pendidikan Nasional. Cetakan Pertama. Jakarta PT Rineka Cipta:

Umar, Tirtarahardja. (2010). Pengantar Pendidikan. Cetakan kedua. Jakarta PT. Rineka Cipta

Undang-undang Republik Indonesia Nomor 32 Tahun 2004 Tentang Pemerintah Daerah.

Undang-undang Republik Indonesia Nomor 12 Tahun 2008 Tentang Pemerintah Daerah.

Undang-undang Republik Indonesia Nomor 20 Tahun 2003 Tentang Sistem Pendidikan Nasional. 